\title{
OPEN
}

Published online: 27 February 2020

\section{Author Correction: Comprehensive analysis of correlations among codon usage bias, gene expression, and substitution rate in Arachis duranensis and Arachis ipaënsis orthologs}

\author{
Hui Song, Hongjuan Gao, Jing Liu, Pei Tian \& Zhibiao Nan
}

Correction to: Scientific Reports https://doi.org/10.1038/s41598-017-13981-1, published online 01 November 2017

The original version of this Article contained a typographical error in the spelling of the author Hongjuan Gao, which was incorrectly given as Hongjun Gao.

In addition, the original version of this Article contained a typographical error in the Materials and Methods section under the subheading 'Identification of orthologs',

"Hence, we excluded ortholog pairs with $K_{\mathrm{a}} / K_{\mathrm{s}}>0.001$."

now reads:

"Hence, we excluded ortholog pairs with $\mathrm{K}_{\mathrm{a}} / \mathrm{K}_{\mathrm{s}}<0.001$."

These errors have now been corrected in the PDF and HTML versions of the Article, and in the accompanying Supplementary materials file.

(i) Open Access This article is licensed under a Creative Commons Attribution 4.0 International License, which permits use, sharing, adaptation, distribution and reproduction in any medium or format, as long as you give appropriate credit to the original author(s) and the source, provide a link to the Creative Commons license, and indicate if changes were made. The images or other third party material in this article are included in the article's Creative Commons license, unless indicated otherwise in a credit line to the material. If material is not included in the article's Creative Commons license and your intended use is not permitted by statutory regulation or exceeds the permitted use, you will need to obtain permission directly from the copyright holder. To view a copy of this license, visit http://creativecommons.org/licenses/by/4.0/.

(c) The Author(s) 2020 